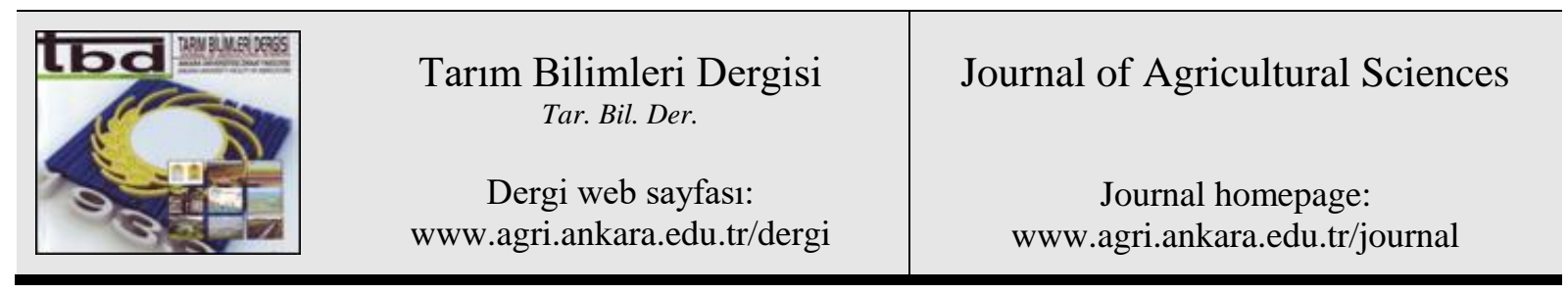

\title{
Assessment of Irrigation Schemes with Performance Indicators in Southeastern Irrigation District of Turkey
}

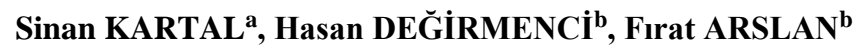

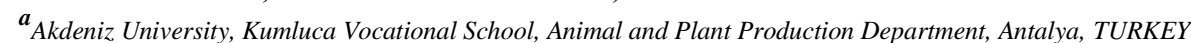

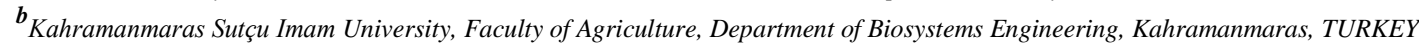

\section{ARTICLE INFO}

Research Article

Corresponding Author: Hasan DEĞİRMENCI, E-mail: hdegirmenci46@gmail.com, Tel: +90 (344) 3002067

Received: 14 January 2019, Received in Revised Form: 08 February 2019, Accepted: 14 February 2019

\section{AUTHORS ORCID ID}

(Sinan KARTAL: 0000-0002-9600-8052), (Hasan DEĞİRMENCİ: 0000-0002-6157-816X), (Furat ARSLAN: 0000-0002-7168-226X)

\section{ABSTRACT}

Water resources are among the most important natural riches of the countries, so this resource must be used correctly and sustainable, especially in the agriculture sector. The Southeastern District of Turkey, has abundant water resources but is known as a region where the problems arising from the excessive use of water. In this study, 5 irrigation schemes (Akçakale, Şanlıurfa, Yaylak Plain, Upper Harran, Bozova) in the Southeastern District of Turkey were chosen as a material to investigate the performance. It is aimed to assess the irrigation schemes in the district with performance indicators used widely by researchers. As an assessment method, ANOVA was used to determine
\end{abstract}

differences of performance indicators among irrigation schemes, multiple regression and correlation were used to explain statistical relation among performance indicators. As a result, irrigation water supplied to users per unit irrigated area $\left(\mathrm{W}_{\text {irrigated }}\right)$ can be explained with irrigation ratio $\left(\mathrm{I}_{\text {ratio }}\right)$, irrigation water supplied to users per unit command area ( $\left.\mathrm{W}_{\text {command }}\right)$, relative water supply $\left(\mathrm{R}_{\mathrm{ws}}\right)$ and output per unit irrigation water supplied to users $\left(\mathrm{O}_{\text {water }}\right)\left(\mathrm{R}^{2}=0.98\right)$. In the region, the average $\mathrm{R}_{\text {ws }}$ was found 2.38 although irrigation methods used by farmers were generally sprinkler. The study also concluded that serious operation, maintenance and management problems exist in the irrigation schemes of the district.

Keywords: ANOVA; Irrigation schemes; Performance assessment; Multiple regression analysis

(C) Ankara Üniversitesi Ziraat Fakültesi

\section{Introduction}

Approximately $70 \%$ of the freshwater in Turkey is consumed in agriculture. Irrigation associations, irrigation cooperatives, village legal entity are responsible for the management of water used in agricultural activities (DSI 2017). The effective use of irrigation water has a vital role in reducing the effects of water scarcity due to global warming (Vörösmarty et al 2000; Flörke et al 2018). In this context, monitoring and evaluation of irrigation schemes are of essential (Degirmenci 2001) in assessing the performance of irrigation schemes. The researchers developed a number of performance indicators for evaluating irrigation schemes (Molden et al 1998) and these indicators were improved with the following studies (Burt 2001; Malano et al 2004) including methodology for modernizing irrigation management (Renault et al 2007). These performance indicators provide an overview of the performance in irrigation schemes. Evaluation of irrigation schemes are also necessary in Turkey, the use of performance indicators used by researchers in many studies aimed to identify strengths and weaknesses of the irrigation schemes (Tanriverdi et al 2011; Degirmenci et al 2017; Elicabuk \& Topak 2017; Arslan \& Degirmenci 2017; Arslan \& Degirmenci 2018; Kiziloglu et al 2018). The evaluation of irrigation schemes with the performance indicators are also widely used in other countries (Rodriguez-Diaz et al 2004; Denis et al 2017; Alcon et al 2017; Zema et al 2018; Muema et al 2018). 
To increase the expected benefits of irrigation schemes, it is necessary to conduct various analyses at regular intervals. Researchers used and developed different analysis methods to evaluate and improve the performance of irrigation schemes. Data envelopment analysis techniques were used to complete deficiency in the interpretation of performance indicators (Rodriguez-Diaz et al 2004). They calculated performance indicators and analyze with multivariate data analysis in some irrigation schemes (Rodriguez-Diaz et al 2008) created the new analysis called quality index including principle component analysis and cluster analysis allows ranking irrigation schemes based on their success. Similar studies carried out by Corcoles et al (2010); Corcoles et al (2012) in Castilla-La Mancha (Spain), Zema et al (2015); Zema et al (2018) in Calabria (Italy) and Kartal (2018) in all irrigation schemes in Turkey, Alcon et al (2017) in Segura River Basin (Spain). All studies indicated the importance of evaluation irrigation schemes in terms of agricultural water management in the world. In parallel studies in Turkey, Cakmak et al (2004) conducted a study in the southeastern part of the country, Tanriverdi et al (2011) assessed the effects of management types of the irrigation schemes, Uysal \& Atis (2010) evaluated Kestel Water User Association in Bursa. Studies done by Kiziloglu et al (2018), Arslan \& Degirmenci (2018), Kalender \& Topak (2017) have been another example of evaluation of irrigation schemes by different performance indicators in Turkey.

The Southeastern District of Turkey is of great importance in terms of irrigation development. This region is located in the Southeastern Anatolian Project (GAP) area wherein the most significant economic and social development project of Turkey erected. Overuse of irrigation water in this region is a major problem due to the lack of infrastructure facilities and management skills (Kartal 2018). In his study, the irrigation schemes in the district were ranked with the overall performance score not separately. The irrigation performance of the region is far from the desired level of success; thus there is need to investigate the district closely Assessment of irrigation schemes by the performance indicators in the district may serve the achievement of sustainable agriculture goals and facilitate the improvement of irrigation performance for decision makers and irrigation managers.

The main aim of this study is to investigate the district including 5 irrigation schemes (Akçakale, Şanlıurfa, Yaylak Plain, Upper Harran, Bozova) located in the Southeastern District of Turkey. The study also focuses on explaining the strengths and weaknesses of them. Eight selected performance indicators among many others calculated for 10 years period and statistical relationships among performance indicators were investigated with ANOVA, correlation and multiple regression analysis in the study.

\section{Material and Methods}

\subsection{Description of study area}

The $15^{\text {th }}$ (Southeastern) District located in GAP area among all 26 Regional Directorates of State Hydraulic Works (DSI) Districts was chosen as the study area. The main characteristics of the irrigation schemes in the study area were given in Table 1. GAP is the largest regional development project in Turkey. GAP is an integrated and multipurpose project aiming to provide social and economic development of the region by mainly irrigation and energy investments including Euphrates and Tigris Basins in 15 ${ }^{\text {th }}$ District of DSI (DSI 2017). This project, which is one of the most significant investments of the Republic Era and developed by DSI, consists of 13 projects including 7 in the Euphrates, 6 in the Tigris Basin. $75 \%$ of energy projects and $29 \%$ of irrigation projects within the context of GAP have been realized so far (DSI 2019).

In the region, 6 irrigation schemes exist including Suruc Plain, Akçakale YAS, Şanlıurfa Harran, Yaylak Plain, Upper Harran and Bozova. These irrigation schemes are managed by water user associations (WUAs) except Suruc Plain which is operated by DSI, not included in this research due to insufficient data. The spatial distributions and locations of the irrigation schemes were given in Figure 1.

The irrigation water is supplied by Ataturk Dam which was built on Euphrates River. Akçakale Irrigation Schemes use only groundwater from 299 wells beside the river. As of 2017, a total area of 433830 ha is irrigated in the region. The annual average precipitation is $400 \mathrm{~mm}$, surface and groundwater potentials are $35185 \mathrm{hm}^{3} \mathrm{year}^{-1}$ and $3443 \mathrm{hm}^{3}$ year-1 $^{-1}$, respectively (DSI 2018).

The total command area in irrigation schemes covers 195527 ha represents $45.07 \%$ of the total irrigated area in the region. Command area of Akçakale YAS, Şanlıurfa Harran, Yaylak Plain, Upper Harran and Bozova 
Irrigation Schemes have 16507, 134366, 18332, 13785 and 12537 ha, respectively (Table 1). Types of irrigation water delivery systems are open channel systems in Akçakale YAS, pipelines in Şanlıurfa Harran, Yaylak Plain, Upper Harran, Bozova Irrigation Schemes. The only canalette type as well as pipelines are used in Şanliurfa Harran scheme to deliver water to farmers. Generally, sprinkler irrigation is the preferred method to irrigate the crops in the study area except for Akçakale YAS and Şanlıurfa Harran schemes where most surface irrigation methods are used. Bozova Irrigation Scheme is the only one in which drip irrigation is the usual method. The main crops are cotton and cereals in the region (Table 1).

Table 1- Main characteristics of the irrigation schemes

\begin{tabular}{lllll}
\hline Irrigation scheme & Command area $(\mathrm{ha})$ & Water diversion & Irrigation method used & Main Crops \\
\hline Akçakale YAS & 16507 & $\begin{array}{l}\text { gravity } \\
\text { pumped }\end{array}$ & Surface (100\%) & Cereals (55\%), Cotton (45\%) \\
Şanliurfa Harran & 134366 & gravity & Surface (100\%) & Cotton (87\%), Cereals (12\%) \\
Yaylak Plain & 18332 & pumped & Sprinkler (100\%) & Cotton (68\%), Peanut (11\%) \\
Upper Harran & 13785 & gravity & Sprinkler (100\%) & Cotton (81\%), Peanut (18\%) \\
Bozova & 12537 & $\begin{array}{l}\text { gravity } \\
\text { pumped }\end{array}$ & $\begin{array}{l}\text { Sprinkler (97\%) } \\
\text { Drip (3\%) }\end{array}$ & Cereals (50\%), Cotton (27\%) \\
\hline
\end{tabular}

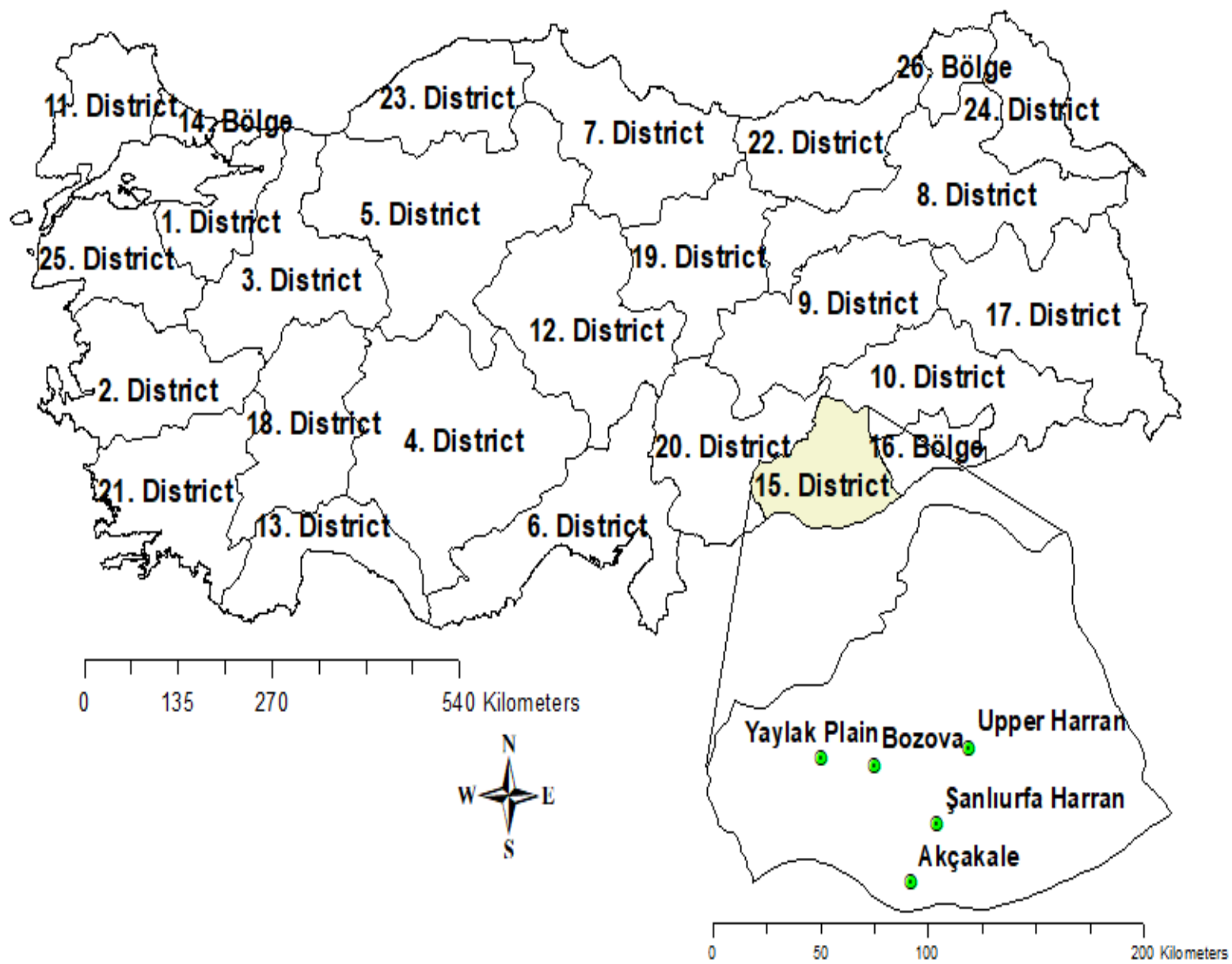

Figure 1- Spatial distribution and location of the irrigation schemes assessed 


\subsection{Data collection}

The data between 2006 and 2016 were obtained from Monitoring and Evaluation Reports of General Directorate of DSI. The reports including command area, irrigated area, irrigation water supplied to users, irrigation water requirements, and agricultural productions are released yearly by DSI.

\subsection{Calculation of performance indicators}

Comparison indicators for performance were used for assessment of irrigation schemes with data from 2006 to 2016. A set of indicators required for performance comparison were chosen based on data availability and appropriateness. Performance indicators used in this study and their calculation formulas were given in Table 2.

Table 2- Performance indicators and their calculation formulas (Molden et al 1998; Burt 2001; Malano \& Burton 2001)

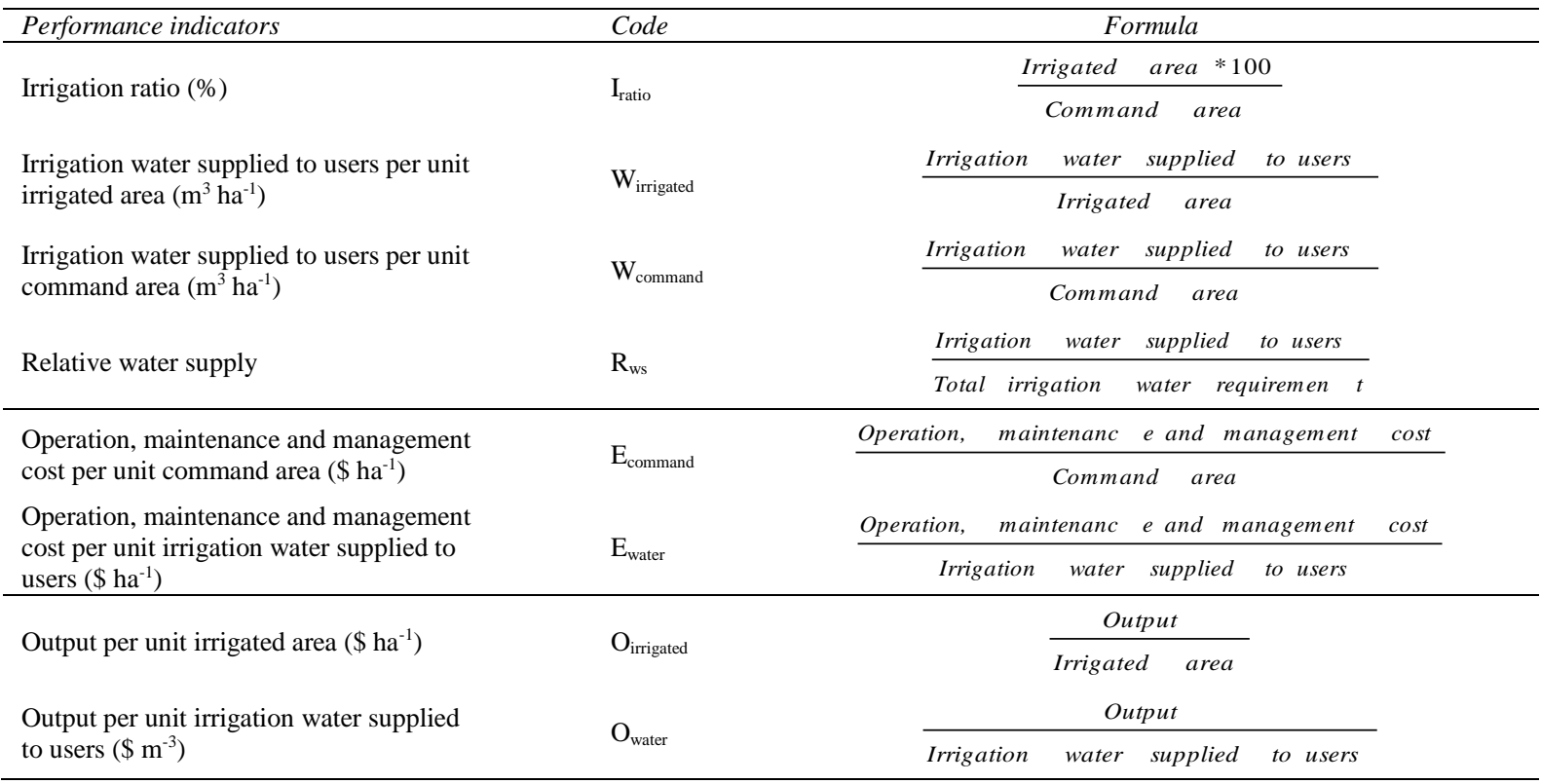

Command area is the total area in the irrigation scheme, where irrigation service can be given. Irrigated area represents the irrigated area including the after crop area. Irrigation water supplied to users is the amount of water taken from the reservoir. The total irrigation water requirement is the amount of water, calculated by CROPWAT considering water delivery and field irrigation efficiency according to crop pattern (Molden et al 1998). The output is the agricultural production obtained from the irrigated area. The output changed into the American dollar (\$) from local currency (Turkish lira) divided average value of the dollar related year with data of Turkish Central Bank.

\subsection{Statistical evaluation}

The analysis of variance (ANOVA, ANalysis Of VAriance) was used to test the difference of the performance indicators among irrigation schemes according to Ozdamar (2017). The hypothesis was established as below:

$\mathrm{H}_{0}$ : There is no difference between the performance indicators' averages.

$\mathrm{H}_{1}$ : There is a difference between the performance indicators' averages.

The correlation was investigated among indicators to determine performance indicators correlated. Shortly, correlations represent the relationships between each estimation variables and the dependent variables by controlling the effects of the other variables. Performance indicators which are correlated the others were chosen to put into the model below according in multiple linear regression analysis. The core aim of the regression model is to explain performance indicators with the others (Alpar 2017). Multiple regression model can be written as: 
$P I=$ cons $+\beta_{1} P I_{1}+\beta_{2} P I_{2}+\cdots+\beta_{i} P I_{i}$

Where; PI, performance indicator; $\beta_{i}$, coefficient of the first estimation variable $I ; P I_{i}$, explanatory variable for the $i$ th observation (dependent PI).

\section{Results and Discussion}

Descriptive statistics were given in Table 3 to provide general information about the district considering all irrigation schemes during the study period. The high rate of standard deviation shows irrigation water supplied to users per unit irrigated and command area were profoundly changed among the study years. This illustrates they are not reliable during the years. The other remarkable result is the leap of relative water supply $\left(R_{w s}\right)$ as high as 7.57. Irrigation water supplied to the farmers was approximately more than twice the irrigation water requirement in the region during the period of the study.

Table 3- Descriptive statistics of performance indicators for all irrigation schemes in the study

\begin{tabular}{lrrrr}
\hline Performance indicators & Minimum & Maximum & Mean & Std. deviation \\
\hline $\mathrm{I}_{\text {ratio }}$ & 40.96 & 91.91 & 72.18 & 14.89 \\
$\mathrm{~W}_{\text {irrigated }}$ & 3320.71 & 34255.51 & 14105.18 & 7018.42 \\
$\mathrm{~W}_{\text {command }}$ & 1859.82 & 27699.74 & 10652.20 & 6437.77 \\
$\mathrm{R}_{\mathrm{ws}}$ & 0.58 & 7.57 & 2.38 & 1.55 \\
$\mathrm{E}_{\text {command }}$ & 31.00 & 2161.95 & 941.00 & 642.26 \\
$\mathrm{E}_{\text {water }}$ & 0.01 & 0.32 & 0.09 & 0.08 \\
$\mathrm{O}_{\text {irrigated }}$ & 2225.75 & 7961.57 & 4383.42 & 1083.19 \\
$\mathrm{O}_{\text {water }}$ & 0.14 & 1.25 & 0.39 & 0.23 \\
\hline
\end{tabular}

$\mathrm{I}_{\text {ratio }}$, irrigation ratio; $\mathrm{W}_{\text {irrigated, }}$, irrigation water supplied to users per unit irrigated area; $\mathrm{W}_{\text {command }}$, irrigation water supplied to users per unit

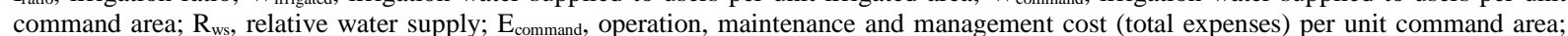

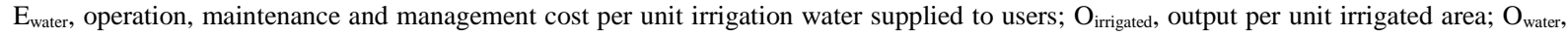
output per unit irrigation water supplied to users

According to ANOVA results which were given in Table 4, there were differences in terms of irrigation ratios' averages among irrigation schemes. Irrigation ratio $\left(\mathrm{I}_{\text {ratio }}\right)$ showed the similarity between Akçakale and Bozova, and among Şanlıurfa-Harran, Yaylak Plain and Upper Harran Irrigation Schemes. Low irrigation ratio (57.64\%) in Akçakale Irrigation Scheme may be attributed to inadequate irrigation facilities (65\%), social and economic problems (17\%), no irrigation water demand (15\%) and the other problems (3\%) according to DSI (2017). Improvement is needed in management and the farm level in Akçakale to increase irrigation ratio. Beside this, groundwater is the primary water source in Akçakale scheme and the main delivery system is open channel with low irrigation efficiency (85\%). Akçakale had the lowest value of irrigation water supplied to users per unit irrigated area $\left(8125.06 \mathrm{~m}^{3} \mathrm{ha}^{-1}\right)$ while Upper Harran had the highest value with $25035.04 \mathrm{~m}^{3} \mathrm{ha}^{-1}$ and there was a significant difference of irrigation water supplied to users per unit irrigated area between irrigation schemes $(\mathrm{P}<0.001)$. Although surface irrigation methods were used throughout the irrigated area in Akçakale while sprinkler irrigation method are used in Upper Harran which shows the lowest performance in terms of $I_{\text {ratio. }}$ We can conclude that the management, maintenance and operation problems may exist in Upper Harran. Assessment of irrigation schemes with RAP (Rapid Appraisal Process) may help to determine more clearly such kind of problems (Burt 2001). Values of irrigation water supplied to users per unit command area ( $\left.\mathrm{W}_{\text {command }}\right)$ shows the situation of the irrigation scheme in case all service area is irrigated. In Akçakale Irrigation Scheme, $\mathrm{W}_{\text {command }} \mathrm{Was}$ not sufficient $\left(4930.58 \mathrm{~m}^{3} \mathrm{ha}^{-1}\right)$ compared to the irrigation water requirement $\left(5537.40 \mathrm{~m}^{3} \mathrm{ha}^{-1}\right)$ calculated by DSI (2017) in case the command area is irrigated totally. The average relative water supply of Akçakale, Şanlıurfa Harran, Yaylak Plain, Upper Harran and Bozova were 1.68, 2.25, 1.70, 4.55 and 1.67, respectively. Irrigation water was used more efficiently in Akçakale, Yaylak Plain and Bozova than the other irrigation schemes and there were no significant differences between the averages of relative water supply. Şanlıurfa Harran and Upper Harran used water inefficiently which was more than twice the water requirement. In a similar study carried out by (Kartal 2018), Akçakale scheme was found as the most successful irrigation scheme in the district with respect to 16 performance indicators. Excessive water use in the region was also reported in his study. In the study carried out 
by (Corcoles et al 2010), $\mathrm{W}_{\text {command }}$ was found between 5200 and $6800 \mathrm{~m}^{3} \mathrm{ha}^{-1}$ in Castilla-La Mancha where sprinkler and drip irrigation widely used. The values obtained from our study are were higher than those of their study.

It is determined that $\mathrm{E}_{\text {command }}$ values statistically similar among 3 groups. Akçakale Irrigation Scheme formed the first group with the lowest average value, Şanlıurfa Harran and Yaylak Plain formed the second group while Upper Harran and Bozova formed the third group which have the highest values (Table 4). The high value of $\mathrm{E}_{\text {command }}$ don't show high performance of the irrigation schemes but it may explain management, operation and maintenance requirement. The averages of total expenses per unit irrigation water supplied to users $\left(\mathrm{E}_{\mathrm{water}}\right)$ were significantly different among the irrigation schemes $(\mathrm{P}<0.001)$ except between Şanliurfa Harran and Upper Harran irrigation schemes $(\mathrm{P}>0.05)$. In this circumstance, we may conclude that management, operation and maintenance requirements were varied among the irrigation schemes in the district. Akçakale has the lowest value of $E_{\text {water }}(0.01$ $\$ \mathrm{~m}^{-3}$ ) while Bozova the highest $\left(0.23 \$ \mathrm{~m}^{-3}\right)$. However, high expenses on irrigation scheme do not show necessarily low or high performance, but they may show the expenses to give healthy irrigation service (Alcon et al 2017).

Table 4- ANOVA results of the performance indicators between irrigation schemes

\begin{tabular}{llllll}
\hline \multicolumn{5}{c}{ Average values of performance indicators } \\
\hline $\begin{array}{l}\text { Performance } \\
\text { indicators }\end{array}$ & $\begin{array}{l}\text { Akçakale } \\
\text { YAS }\end{array}$ & $\begin{array}{l}\text { Sanliurfa } \\
\text { Harran }\end{array}$ & $\begin{array}{l}\text { Yaylak } \\
\text { Plain }\end{array}$ & $\begin{array}{l}\text { Upper } \\
\text { Harran }\end{array}$ & Bozova \\
\hline $\mathrm{I}_{\text {ratio }}$ & $57.63^{\mathrm{d}}$ & $79.70^{\mathrm{ab}}$ & $69.62^{\mathrm{cb}}$ & $86.47^{\mathrm{a}}$ & $67.46^{\mathrm{cd}}$ \\
$\mathrm{W}_{\text {irrigated }}$ & $8125.06^{\mathrm{c}}$ & $14550.28^{\mathrm{b}}$ & $11934.85^{\mathrm{bc}}$ & $25035.04^{\mathrm{a}}$ & $10880.65^{\mathrm{bc}}$ \\
$\mathrm{W}_{\text {command }}$ & $4930.58^{\mathrm{d}}$ & $11608.90^{\mathrm{b}}$ & $8172.18^{\mathrm{c}}$ & $21484.63^{\mathrm{a}}$ & $70654.7^{\mathrm{cd}}$ \\
$\mathrm{R}_{\text {ws }}$ & $1.68^{\mathrm{b}}$ & $2.25^{\mathrm{b}}$ & $1.70^{\mathrm{b}}$ & $4.55^{\mathrm{a}}$ & $1.67^{\mathrm{b}}$ \\
E $_{\text {command }}$ & $69.06^{\mathrm{c}}$ & $742.72^{\mathrm{b}}$ & $848.96^{\mathrm{b}}$ & $1382.00^{\mathrm{a}}$ & $1662.26^{\mathrm{a}}$ \\
E $_{\text {water }}$ & $0.01^{\mathrm{d}}$ & $0.06^{\mathrm{c}}$ & $0.10^{\mathrm{b}}$ & $0.06^{\mathrm{c}}$ & $0.23^{\mathrm{a}}$ \\
Oirrigated & $3405.84^{\mathrm{d}}$ & $3922.60^{\mathrm{cd}}$ & $5003.83^{\mathrm{ab}}$ & $4292.14^{\mathrm{bc}}$ & $5292.66^{\mathrm{a}}$ \\
O $_{\text {water }}$ & $0.60^{\mathrm{a}}$ & $0.27^{\mathrm{bc}}$ & $0.43^{\mathrm{ab}}$ & $0.17^{\mathrm{c}}$ & $0.50^{\mathrm{a}}$ \\
\hline
\end{tabular}

The correlation was investigated to determine the statistical relation among performance indicator and Pearson correlation result is given in Table 5. However the main aim of the correlation was to use the performance indicators as explanatory to the other in the regression model (Table 6). Since the irrigated area is close to the command area in terms of size, the highest correlation was found between $\mathrm{W}_{\text {irrigated }}$ and $\mathrm{W}_{\text {command. }}$.

Table 5- Correlations among performance indicators

\begin{tabular}{|c|c|c|c|c|c|c|c|c|}
\hline $\begin{array}{l}\text { Performance } \\
\text { indicators }\end{array}$ & $I_{\text {ratio }}$ & $W_{\text {irrigated }}$ & $W_{\text {command }}$ & $R_{w s}$ & $E_{\text {command }}$ & $E_{\text {water }}$ & $O_{\text {irrigated }}$ & $O_{\text {water }}$ \\
\hline $\mathrm{I}_{\text {ratio }}$ & 1 & $0.461^{* *}$ & $0.653^{* *}$ & $0.358^{*}$ & $0.375^{*}$ & -0.027 & 0.031 & $-0.443^{* * *}$ \\
\hline $\mathrm{W}_{\text {irrigated }}$ & & 1 & $0.962^{* *}$ & $0.873^{\text {** }}$ & 0.276 & -0.206 & 0.014 & $-0.764^{* *}$ \\
\hline $\mathrm{W}_{\text {command }}$ & & & 1 & $0.825^{* *}$ & $0.308^{*}$ & -0.234 & -0.009 & $-0.726^{* *}$ \\
\hline $\mathrm{R}_{\mathrm{ws}}$ & & & & 1 & 0.076 & -0.264 & -0.067 & $-0.637^{* *}$ \\
\hline$E_{\text {command }}$ & & & & & 1 & $0.766^{* *}$ & $0.501^{* *}$ & -0.194 \\
\hline $\mathrm{E}_{\text {water }}$ & & & & & & 1 & $0.582^{* *}$ & 0.180 \\
\hline $\mathrm{O}_{\text {irrigated }}$ & & & & & & & 1 & 0.289 \\
\hline $\mathrm{O}_{\text {water }}$ & & & & & & & & 1 \\
\hline
\end{tabular}


Table 6- Multiple linear regression models

\begin{tabular}{|c|c|c|c|}
\hline Indicators & Model & $R^{2}$ & $P$ value \\
\hline Iratio & Iratio $=84.15-0.005 \times$ Wirrigated $+0.07 \times$ Wcommand $-18.26 \times$ Owater & 0.84 & 0.000 \\
\hline Wirrigated & $\begin{array}{c}\text { Wirrigated }=11979.69-121.13 \times \text { Iratio }+1.06 \times \text { Wcommand }+401.78 \\
\text { x Rws }-3474.21 \times \text { Owater }\end{array}$ & 0.98 & 0.000 \\
\hline $\mathrm{W}_{\text {command }}$ & $\begin{array}{c}\text { Wcommand }=-3875.97+137.96 \times \text { Iratio }+2400.63 \times \text { x } w s+1.07 \\
\text { x Ecommand }-5369.10 \times \text { Owater }\end{array}$ & 0.86 & 0.000 \\
\hline $\mathrm{R}_{\mathrm{ws}}$ & $R w s=-0.36-0.005 \times$ Iratio $+0.414 \times$ Owater & 0.77 & 0.000 \\
\hline E $_{\text {command }}$ & $\begin{array}{c}\text { Ecommand }=-537.47+4.80 \times \text { Iratio }+0.04 \times \text { Wcommand }+6938.76 \\
\mathrm{x} \text { Ewater }-0.01 \times \text { Oirrigated }\end{array}$ & 0.84 & 0.000 \\
\hline Ewater & Ewater $=-0.06+8 \times 10^{-5} \times$ Ecommand $+1.9 \times 10^{-5} \times$ Oirrigated & 0.64 & 0.000 \\
\hline $\mathrm{O}_{\text {irrigated }}$ & Oirrigated $=3538.20+0.23 \times$ Ecommand $+6398.59 \times$ Ewater & 0.35 & 0.000 \\
\hline $\mathrm{O}_{\text {water }}$ & $\begin{array}{c}\text { Owater }=1.44-0.009 \times \text { Iratio }-8.021 \times 10^{-5} \times \text { Wirrigated }+6.81 \times 10^{-5} \times \text { Wcommand }+ \\
0.02 \times R w s\end{array}$ & 0.66 & 0.000 \\
\hline
\end{tabular}

The highest average $\mathrm{O}_{\text {irrigated }}$ was found as $5292.66 \$ \mathrm{ha}^{-1}$ in Bozova Irrigation Scheme while the lowest value (3404.84 $\$ \mathrm{ha}^{-1}$ ) was seen in Akçakale. Yaylak Plain has the highest value of average output per unit irrigation water supplied to users $\left(0.44 \$ \mathrm{~m}^{-3}\right)$ while Upper Harran has the lowest value $\left(0.18 \$ \mathrm{~m}^{-3}\right)$. Bozova and Akçakale Irrigation Schemes' crop patterns were similar which is the main reason increasing the output. Nevertheless, the output (production) obtained from per unit area depends on factors such as irrigation method used, farmers'

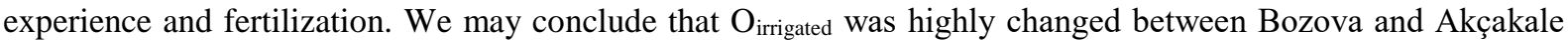
due to these parameters (irrigation methods, farmer' experience, fertilization etc.). The crop pattern of Yaylak Plain Irrigation Scheme consists of cotton (68\%) and peanut (11\%) while Upper Harran' crop pattern consists of cotton $(81 \%)$ and peanut $(18 \%)$ as main crops. Under the circumstances, Upper Harran should have higher values of $\mathrm{O}_{\text {irrigated }}$ than Yaylak Plain Irrigation Scheme with regard to the crop pattern. This situation may be explained by internal problems as well. As it was reported in a study from Turkey (Degirmenci 2001), irrigation schemes were divided into three groups in terms of the command area. In the first group, the value of output per unit irrigated area was 1000-2000 \$ ha-1 in 66 irrigation schemes, 2000-3000 \$ ha-1 in 40 irrigation schemes in the second, and more than $3000 \$ \mathrm{ha}^{-1}$ in 38 irrigation schemes in the last group. Irrigation schemes in the region fall within the third group.

The models showed that $\mathrm{W}_{\text {irrigated }}$ can be explained with $\mathrm{I}_{\text {ratio }}, \mathrm{W}_{\text {command }}, \mathrm{R}_{\mathrm{ws}}$ and $\mathrm{O}_{\text {water }}$. This explains $\mathrm{W}_{\text {irrigated }}$ was affected the most by the other indicators. We can conclude the interdependence of performance indicators from models. $W_{\text {irrigated }}$ was the performance indicator having the strongest relation correlation with others $\left(\mathrm{R}^{2}=\right.$

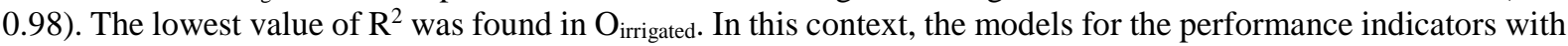
high $\mathrm{R}^{2}$ can be used to estimate unknown indicators for the region.

When we consider the overall assessment of the study, we may conclude that $\mathrm{W}_{\text {irrigated }}$ was exceptionally high which may originate from irrigation water management problems. Applying modernization procedures in irrigation schemes may help to use irrigation water efficiently and irrigation performance may be enhanced (Playan \& Mateos 2006; Renault et al 2007; Lecina et al 2010). Although water user associations in Turkey were operated by a president who is one of the farmer-elected by other farmers' votes, DSI currently decided to assign an engineer in WUAs management. In this context, this action may be interpreted as a rational process of Turkey government to resolve problems of water management and to encourage farmers in adopting modern irrigation methods. However, agricultural extension and consultancy services to farmers are of relevant importance in increasing water use efficiency and agricultural production (Gumus \& Kaya 2014).

In the current study, we figure out some performance indicators that can be explained by the other indicators according to multiple regression which similar method with Alcon et al (2017). They used panel data regression models to demonstrate the effects of Irrigation Communities' attributes such as water performance, rotation schedule, and energy prices on performance indicators in the arid region of Spain. One another study conducted by Zema et al (2015) in Italy, it was stated that there was a strong correlation between performance indicators, was also support the study of (Rodriguez-Diaz et al 2004) who ranked WUAs with factor analysis. Irrigation water was efficiently used in the arid and water shortage regions where above-mentioned studies were carried out. However, we met weak performance of irrigation schemes and inefficient water use in our study area which is also located in the arid part of Turkey. 


\section{Conclusions}

The irrigation schemes evaluated have differences or similarities in terms of the average performance indicators in the district for the study years. Despite the fact that sprinkler irrigation is a predominant method in the application of water and the pipeline systems are mostly involved in water delivery in the district, irrigation water was mostly overused in the schemes and the agricultural production per unit irrigated area, irrigation water was low in most of the cases. Therefore, operation, maintenance and management of irrigation schemes should be reviewed and improved to eliminate inefficiency. In the region, output per unit irrigated area was found low although the crop pattern with high production values. Thus, agricultural extension and consultancy services should be enlarged to increase agricultural production.

\section{References}

Alcon F, Garcia-Bastida P A, Soto-Garcia M, Martinez-Alvarez V, Martin-Gorriz B \& Baille A (2017). Explaining the Performance of Irrigation Communities in a Water-scarce Region. Irrigation Science 35(3): 193-203

Alpar R (2017). Çok Degiskenli Istatistiksel Yontemler. Detay Yayimcilik. Istanbul, ISBN: 978-605-5437-42-B

Arslan F \& Degirmenci H (2017). Rating of Some Irrigation Projects Operated by DSI in Turkey. International Advanced Researches \& Engineering Congress-2017, 16-18 Nov, Osmaniye, Turkey, pp. 2360-2735

Arslan F \& Degirmenci H (2018). RAP-MASSCOTE Approach of Modernizing Operation-maintenance and Management of Irrigation Schemes: a Case Study of Kahramanmaraş Left Bank Irrigation Scheme. Ataturk University Journal of the Agricultural Faculty 49(1): 45-51

Burt C (2001). Rapid Appraisal Process (RAP) and Benchmarking: Explanation and Tools. Retrieved in August, 18, 2018 from http://www.watercontrol.org/tools/rap-eng-2002

Cakmak B, Beyribey M, Yildirim Y E \& Kodal S (2004). Benchmarking Performance of Irrigation Schemes: a Case Study from Turkey. Irrigation and Drainage 53(2): 155-163

Corcoles J I, de Juan J A, Ortega J F, Tarjuelo J M \& Moreno M A (2010). Management Evaluation of Water Users Associations using Benchmarking Techniques. Agricultural Water Management 98: 1-11

Corcoles J I, de Juan J A, Ortega J F, Tarjuelo J M \& Moreno M A (2012). Evaluation of Irrigation Systems by using Benchmarking Techniques. Journal of Irrigation and Drainage Engineering 138(3): 225-234

Degirmenci H (2001). Devredilen sulama sebekelerinin karsilastirma gostergeleri ile degerlendirilmesi. Uludağ Universitesi Ziraat Fakultesi Dergisi: 15: 31-41

Degirmenci H, Tanriverdi C, Arslan F \& Gonen E (2017). Benchmarking Performance of Large Scale Irrigation Schemes with Comparative Indicators in Turkey. Scientific Papers. Series E. Land Reclamation, Earth Observation and Surveying, Environmental Engineering 6: 87-92

Denis A, Suryavanshi S \& Yadav A (2017). Irrigation performance assessment of a Canal irrigated area: A case study of Samrakalwana Village in Allahabad. Journal of Indian Water Resources Society 37(4): 17-24

DSI (2017). 2016 Y1l DSI'ce isletilen ve devredilen sulama tesisleri degerlendirme raporu. General Directorate of State Hydraulic Works, Ankara, Turkey

DSI (2018). Irrigation schemes. 15th district general directorate of state hydraulic works. Retrieved in December, 11 from URL. http://bolge15.dsi.gov.tr/toprak-ve-su-kaynaklar\%C4\%B1

DSI (2019). Guneydogu Anadolu projesi kalkinma idaresi baskanligi tarihcesi. Retrieved in February, 14, 2019 from http://www.gap.gov.tr/gap-bki-tarihcesi-sayfa-37.html

Elicabuk C \& Topak R (2017). Evaluation of Irrigation Performance in Gevrekli Irrigation Association. Selcuk Journal of Agriculture and Food Sciences 3(2): 191-199

Flörke M, Schneider C \& McDonald R I (2018). How agriculture can ease the global urban water shortage. Farmer's Weekly 2018(18006): 6-7

Journal of Agricultural Sciences (Tarmm Bilimleri Dergisi) 26 (2020) 138-146 
Gumus I U \& Kaya C (2014). GAP Tarımsal eğitim ve yayım projesi çiftçi örgütleri merkezli çoğulcu yayım modeli. Ulusal Aile Çiftçiliği Sempozyumu, 30-31 October, Ankara, pp. 407-411

Kalender M A \& Topak R (2017). Irrigation performance of Ilgin plain irrigation association. Selcuk Journal of Agriculture and Food Sciences 31(2): 59-67

Kartal S (2018). Sulama şebeke performanslarının çok değişkenli istatistiksel yöntemlerle değerlendirilmesi: Türkiye örneği. PhD Thesis, Kahramanmaras Sucu Imam University (Unpublished), TR

Kiziloglu F M, Sahin U, Diler S \& Oztaskin S (2018). Evaluation of irrigation system performance in the first and second stage irrigation scheme of Erzurum Daphan Plain irrigation associations (2012-2016). Turkish Journal of Agriculture-Food Science and Technology 6(10): 1381-1387

Lecina S, Isidoro D, Playán E \& Aragüés R (2010). Irrigation modernization and water conservation in Spain: The case of Riegos del Alto Aragón. Agricultural Water Management 97(10): 1663-1675

Malano H \& Burton M (2001). Guidelines for benchmarking performance in the irrigation and drainage Sector, IPTRID and FAO, Rome, Italy. 2001

Malano H, Burton M \& Makin I (2004). Benchmarking Performance in the irrigation and drainage sector: a Tool for Change. Irrigation and Drainage: 53:119-133

Molden D J, Sakthivadivel R, Perry C J \& De Fraiture C (1998). Indicators for Comparing Performance of Irrigated Agricultural Systems. International Water Management Institute, Colombo, Research Report 20: 26

Muema F, Home P \& Raude J (2018). Application of benchmarking and principal component analysis in measuring performance of public irrigation schemes in Kenya. Agriculture 8(10): 162

Ozdamar K (2017). Paket Programlar ile Istatistiksel Veri Analizi. Nisan Yayımcılık, Ankara

Playan E \& Mateos L (2006). Modernization and optimization of irrigation systems to increase water productivity. Agricultural Water Management 80: 100-105

Renault D, Facon T \& Wahaj R (2007). Modernizing Irrigation Management: The MASSCOTE Approach-Mapping System and Services for Canal Operation Techniques, FAO Irrigation and Drainage Paper 63, pp. 207

Rodriguez-Diaz J A, Poyato E C \& Luque R L (2004). Applying benchmarking and data envelopment analysis (DEA) techniques to irrigation districts in Spain. Irrigation and Drainage 53(2): 135-143

Rodriguez-Diaz J A, Camacho E, Lopez R \& Perez L (2008). Benchmarking and multivariate data analysis techniques for improving the efficiency of irrigation districts: an application in Spain. Agricultural Systems 96: 250-259

Tanriverdi C, Degirmenci H \& Sesveren S (2011). Assessment of irrigation schemes in turkey based on management types. African Journal of Biotechnology 10(11): 1997-2004

Uysal O K \& Atis E (2010). Assessing the performance of participatory irrigation management over time: a case study from Turkey. Agricultural Water Management 97(7): 1017-1025

Vörösmarty C J, Green P, Salisbury J \& Lammers R B (2000). Global water resources: vulnerability from climate change and population growth. Science 289(5477): 284-288

Zema D A, Nicotra A, Tamburino V \& Zimbone S M (2015). Performance assessment of collective irrigation in water users' Associations of Calabria (Southern Italy). Irrigation and drainage 64(3): 314-325

Zema D A, Nicotra A, Mateos L \& Zimbone S M (2018). Improvement of the irrigation performance in water users Associations integrating data envelopment analysis and multi-regression models. Agricultural Water Management 205: 38-49 